\title{
The Use of Student Worksheets Based on a Science Approach in Internalizing the Attitudes and Character of Elementary School Students
}

\author{
Supriyadi ${ }^{1}$; Nelly Astuti ${ }^{2}$; Ika Wulandari Utami Ningtias ${ }^{3}$; Amrina Izzatika ${ }^{4}$ \\ Elementary School Teacher Education, Faculty of Teacher Training and Education, University of Lampung, \\ Lampung, Indonesia
}

http://dx.doi.org/10.18415/ijmmu.v8i2.2323

\begin{abstract}
The implementation of the 2013 Curriculum is a real step for the Indonesian government in improving the quality of human resources in the era of globalization. The curriculum has the concept of an integrated learning system between spiritual attitudes, social attitudes, skills and knowledge. However, in its implementation in the classroom, there are many inconsistencies in the learning concept with the curriculum, especially in the application of attitude and character learning. For that we need a media that can support the implementation of the internalization of students' attitudes and characters in learning, one of which is student worksheets based on a scientific approach. This study aims to determine the effect of using scientific approach-based student worksheets on the internalization of students' attitudes and character. Participants involved in this study were 54 elementary school students in Metro City, Lampung Province, Indonesia. The research was conducted with a mix method, through direct observation and tests. The results showed that there were attitudes and characters that emerged during the learning process using student worksheets based on a scientific approach at the stages of observing, asking questions, collecting information, analyzing data, and communicating the results of data analysis. Meanwhile, quantitative analysis using the Chi Square Test shows that there are significant differences in learning outcomes when using student worksheets based on a scientific approach. Based on these results, student worksheets based on a scientific approach can be used to internalize the attitudes and character of students.
\end{abstract}

Keywords: Student Worksheets; Scientific Approach; Attitude Education; Character Education

\section{Introduction}

The condition of global competition in the Industrial 4.0 era demands that the Indonesian government immediately prepare its human resources to be of higher quality (Nirbita, 2020; Astalini, Kurniawan, Perdana, and Pathoni, 2019). Education as a producer of quality human resources is an aspect that must be adapted to the times. This adjustment resulted in an education system concept called Curriculum 2013. There are four competencies that are emphasized in this curriculum, namely spiritual attitudes, social attitudes, skills and knowledge (Novianto and Mustadi, 2015; Marini et al., 2019). Of the four competencies, it can be explained that the purpose of the 2013 Curriculum formulation is to form students who have noble attitudes, values and character by instilling and implementing character 
education in all subjects. Especially in the field of science, the 2013 Curriculum seeks to arouse human interest and curiosity so that intelligence and understanding of nature continues to develop. Based on this, in essence this curriculum emphasizes the achievement of scientific attitudes and student character. Because the success of learning in school is not only based on cognitive aspects, but also must be viewed from the aspect of attitude (Marini et al., 2019).

However, unfortunately the concepts that have been compiled in the 2013 Curriculum are not accompanied by appropriate applications in schools, especially in natural science subjects in elementary schools. The learning that is currently happening in the natural science learning process is still conventional and only emphasizes the preparation of students to continue higher studies, not to prepare the quality of human resources who are critical, sensitive to the environment, creative, and understand the simple technology that is present in in the midst of society (Wirtha and Rapi, 2008). This is also reinforced by the statement by Ribau (2020) that the problem that often arises in the learning process in class is the difficulty of developing scientific skills. In fact, things that are very important in learning natural science are 1) skills to be able to solve problems faced in life using scientific concepts that have been learned; 2) skills to be able to make correct decisions using scientific concepts; and 3) have a scientific attitude in solving the problems faced so that they can think and act scientifically.

In addition, the learning process also only transfers knowledge to students without instilling noble and noble values, which has an impact on moral degeneration and irresponsible behavior. As a result, there is an attitude of indifference to the environment which is a reflection of the past education system in the present. This is because the previous education system had not accommodated the inculcation of attitudes, values and character in learning. The results of observations also show that: 1) the learning process is still centered on educators; 2) students lack the initiative to ask questions; 3 ) if the educator gives a question, no one will answer but several students will answer simultaneously so that the voice is not clear; 4) when doing exercises or activity sheets contained in student books, some students do it by guessing without reading it first; 5) if asked a question about the relationship between theory and application in everyday life, students will give the answer according to the book; and 6) there are still some students who like to laugh at their friends when asked to come to the front of the class. This condition shows that the character values possessed by students are still not good. Even though character is closely related to a person's moral values or character.

Character is a relatively stable person's disposition, who upholds the main ethical values such as respect / respect, responsibility, honesty, fairness and care (Afrizon, 2012; Albaracin, Johnson, and Zanna, 2005). The emergence of this character value is related to understanding (head), caring (heart), and action (hand) instilled through habituation (Machin, 2014). There are four characters that can be developed during the learning process, namely cultural value-based characters, culture-based characters, environment-based characters, and self-potential-based characters (Leksono, 2013). Character based on cultural values is closely related to divinity (moral conservation). Culture-based characteristics are closely related to habituation and character cultivation, such as character, the exemplary of certain figures, and so on. Environment-based characteristics relate to a person's interactions with the surrounding environment. And self-potential-based interactions are related to personal attitudes, awareness of self-potential empowerment, and so on. There are four types of conservation characters that can be developed during the educational process, namely (1) character education based on cultural values, which is the truth of God's revelation (moral conservation); (2) character education based on culture, including in the form of character, Pancasila, literary appreciation, exemplary historical figures and national leaders (cultural conservation); (3) character education based on environment (environmental conservation), and (4) character education based on self-potential, namely personal attitudes, the result of the awareness process of self-potential empowerment directed at improving the quality of education (humanist conservation) (Leksono , 2013). 
From these conditions, a learning process is needed that can initiate students to ask questions, answer questions independently, and discover concepts taught through a series of investigation and study activities. With such learning, the learning process will be more meaningful. To create good learning conditions in the classroom, in the learning process, a teacher is required to be able to organize, select and implement learning strategies that are suitable for the student's conditions and the environment being taught, so that students feel like science subjects and learning objectives that have been determined to be achievable (Maretasari, Subali, and Hartono, 2012; Akpinar, Yildiz, Tatar, and Ergin, 2009). One of the appropriate lessons to achieve this competency is learning with a scientific approach.

The scientific approach is a basic concept that embodies, inspires, strengthens, and underlies thoughts on how learning methods are applied based on certain theories (Ministry of Education and Culture, 2013). In learning with a scientific approach, it involves the process of observing, asking questions, gathering power (experiment), analyzing data, and communicating (Ministry of Education and Culture, 2013; Saefudin and Saputri, 2018). In addition, learning with a scientific process can also be carried out by a process of investigation, experiment, evaluation of evidence, and conclusion (Zimmerman, 2007). The learning process will be able to train students to have reasoning skills and become experts in their fields (Nasser, 2014; Lederman, Lederman, and Antink, 2013; Setiawan, Malik, Suhandi, and Permanasari, 2018). With reasoning skills, students will be able to face a problem with the knowledge they have acquired.

The application of a scientific approach to the learning process can be integrated into teaching materials, one of which is the Student Worksheet. Student Worksheets are not only useful for educators but also for students to guide their activities to solve problems given in learning (Majid, 2012; Rahmi et al., 2017; Permana, 2000). The development of Student Worksheets must be in accordance with the demands of curriculum development and students (Rahmi and Alberida, 2017). The scientific approach to the 2013 curriculum requires students to take an active role in the learning process. This will be easier if combined with teaching materials in the form of Student Worksheets. The advantage of using Student Worksheets is that they can make it easier for teachers to learn and familiarize students to learn independently and understand and carry out tasks in writing (Ministry of National Education, 2008; Marsa, Hala, and Taiyeb, 2016). With the use of Student Worksheets, students' motor activities, especially school age 7 to 12 years will be initiated. So that the internalization of students' attitudes and characters in scientific activities can run on the learning process.

\section{Materials and Methods}

This research was conducted with a mix method research. Mix method research is a research method that is applied if the researcher has questions that need to be tested in terms of outcomes and processes, and involves a combination of quantitative and qualitative methods in one study (Masrizal, 2011; Hastjarjo, 2019; Sugiyono, 2016). A qualitative approach is carried out to see the learning process so that it can observe students' attitudes and characters carefully. While the quantitative approach is carried out to see the results of the learning process with statistical data processing.

The data analysis was carried out based on the students' pretest and posttest scores on the material about plants. The research design used was a pre-experimental design in the form of One Group PretestPostest. The One Group design is a research design that looks at the pre-treatment conditions and compares them to the conditions at post-treatment (Hastjarjo, 2019). This design allows researchers to see whether a treatment can have an effect on the object. Based on this, in this study participants will be given a pretest before the treatment is given. Furthermore, participants will be given treatment, namely learning using student worksheets based on a science approach. The posttest was given after the treatment was completed to the participants during the learning process. In summary, an overview of this design can be seen in Figure 1. 
Note:

$\mathrm{O}_{1} \quad$ : Pretest value

$\mathrm{O}_{2} \quad$ : Posttest value

$\mathrm{X} \quad$ : Treatment (use of student worksheets)

Figure 1. One Group Pretest - Posttest Research Design

\section{Participants}

The number of participants involved in this study were 54 elementary school students in grade 4 in Metro City, Lampung Province, Indonesia. The determination of participants is based on the results of preliminary observations, where the class conditions are less active during the learning process, the learning process is still familiar with the teacher-centered concept, and the learning outcomes are still unsatisfactory.

\section{Data Collection Techniques}

Data collection was carried out in two ways, namely observation and tests. The observation technique is carried out to see firsthand how the learning process takes place. Observations were made by focusing on the character and attitudes of students during the learning process using student worksheets based on a scientific approach.

The test was given twice, namely pretest and postest. Pretest is given before treatment is given, while postest is given after treatment. Before being used, the two test instruments were tested for validity and reliability first. Validity measurement is carried out because it relates to the ability of the instrument to measure what should be measured (Baehaki, Nahadi, and Firman, 2016). The validity values of the pretest and posttest instruments were 0.76 and 0.78 , respectively. This value is based on the results of the validity test using the correlation test, where the value indicates a good validity value. Meanwhile, the reliability value is based on the Cronbach Alpha value. The value obtained is 0.92 , so it is included in the very high reliability category.

\section{Data Analysis}

Data analysis was carried out in two ways, namely qualitative and quantitative. The qualitative approach is carried out by describing the results of the observations during the learning process. Researchers made observations by focusing on the value of students' attitudes and characteristics during the process.

The quantitative approach was carried out based on the student's pretest and posttest value data. Different test is applied to the data, however the determination of the difference test is carried out after the data is tested for normality. If the data distribution is normal, then the difference test used is the T test. However, if the data distribution is not normal, then the different test used is Chi Square.

\section{Results and Discussions}

\section{Qualitative Analysis: Results of Observation of Student Attitudes and Character}

The learning process that is applied is in accordance with the concepts or designs that have been made previously. Where the learning process is carried out using student worksheets based on a scientific 
approach. The developed student worksheets will guide them through the learning process with the following stages: 1) observing; 2) ask: 3) collect information; 4) analyzing data; and 5) communicate. This is done because the learning process will initiate students directly in inferring existing problems in the form of problem formulations and hypotheses, a sense of care for the environment, curiosity and love to read. In doing so, students will have the opportunity to carry out investigations and inquiries and develop and present their work. Through investigation and inquiry students will be stimulated to think analytically, behave honestly, discipline, creatively and independently. The activity of presenting the work will lead to creative behavior, respect for existing achievements, being responsible for the work, the ability to cooperate and communicate well. In the final stage students will be invited to analyze and evaluate the problem solving process. At this stage students will think at the level of analysis and evaluation because they have to reflect on the process they are doing. Yenice and Saydam (2010) also said that scientific attitudes will increase when learning is focused on student activities. Based on this description, the observation of students' attitudes and characteristics was carried out at the learning stage including the stages of observing, asking questions, collecting information, analyzing data, and communicating.

The observing stage. At this stage, the student worksheet presents a problem, phenomenon, and data so that students will begin to observe. With the provision of this stimulus, students begin to grow curiosity, even though there are some students who still have not shown an attitude of curiosity. The emergence of curiosity in most of the students is an opportunity for teachers to be more active in observing activities. The teacher also opens wide opportunities for students to make observations through listening, seeing, reading, and listening. The characters that appear at this stage are training sincerity, thoroughness, seeking information and environmental conservation.

The asking stage. At this stage, the teacher openly provides broad opportunities for students to ask questions about the results at the observation stage (what has been seen, listened to, read, and seen). More student activity with the number of students scrambling to ask questions. Therefore, the teacher began to adjust the conditions of the class to be more orderly and gave turns to ask questions. The existence of this questioning stage aims to develop their curiosity. The questions asked will be the basis for them to find more information from the source determined by the teacher and students. The characters that appear at this stage are the desire to develop creativity, curiosity, the ability to formulate questions, and form critical thoughts.

Collecting data stage. At this stage, students are directed to seek and extract information from various reliable sources, such as books or re-observing objects by conducting experiments. Experiments can be done by looking more deeply at the structure of the plant to see its parts in more detail. In this activity, students were also involved in the discussion process with their friends so that their communication skills were trained. The characters that appear at this stage are honesty, thorough, polite, respect for other people's opinions, the ability to communicate, apply the ability to gather information, and develop learning habits.

Analyze data stage. The data collected at the data collection stage or information is then analyzed. It seems that at this stage the students find it difficult. This is natural because so far they are used to only receiving information in the learning process. However, they still try to analyze the data that has been collected. This activity is carried out by finding the linkages of one information with other information, finding patterns of related information. Thus they will be familiar with how to think using reasoning skills (logical and systematic thinking on observable empirical facts to obtain conclusions in the form of knowledge). Data analysis is directed by the teacher through student worksheets to add depth to understanding and find solutions to different opinions. This is because after gathering the information, they have come to their own conclusions. So there needs to be a confirmation stage involving the teacher. This activity is continued with the stage of drawing conclusions based on the linkages between one 
information and another. The characters that appear in this activity are developing an attitude of honesty, conscientiousness, discipline, obeying rules, hard work, the ability to apply procedures and the ability to think inductively and deductively in concluding.

Stage of communicating. At this stage, the teacher directs students to retell what they have learned through student worksheets. At this stage students are directed to rewrite the experiences from the learning gained and present them in front of other students. It aims to practice public speaking skills. The characters that appear at this stage are communication skills, respect for opinions, and the ability to relate experiences to one another.

In the learning process, learning outcomes can be viewed from three aspects, namely attitudes, knowledge, and skills. The attitude that stands out in the learning process is the attitude of accepting, carrying out, appreciating, appreciating, and practicing. All learning activities are oriented towards cultivating character that encourages students to do these activities. The knowledge aspect is measured and observed through the activities of knowing, understanding, applying, analyzing, evaluating, and creating. The characteristics of learning activities in the knowledge domain have differences and similarities with learning activities in the skills domain. Using a learning approach that produces work to encourage students to produce creative and contextual work, both individually and in groups, Aspects of skills are obtained through observing, questioning, trying, reasoning, presenting, experimenting and creating. The entire content of plant material must encourage students to carry out the process of observation to creation. To realize these skills, it is necessary to carry out learning that applies a learning approach that produces work based on environmental conservation. In addition, working scientifically also trains them to have certain attitudes or values, such as avoiding dogmatism, being flexible, creative, honest, logical, open to criticism, conscientious, loving duty and understanding risks. All of these values are the foundation of scientific work. If students are accustomed to being involved in scientific work, students will inherit these values and attitudes, as important values also in character development.

With the learning habit as described earlier, the process of internalizing character education based on the objectives of the 2013 Curriculum will be achieved. There are many reasons that indicate the need to internalize character and attitudes towards students, namely 1) the role of schools is becoming increasingly vital because many students receive little moral instruction from parents, society, or religious institutions; 2) democratic habituation requires a special need for moral education because democracy is a regulation from, for and by society; 3 ) effective character education makes schools more civilized, cares about the community and refers to increased academic performance; and 4) the cultivation of morals in the younger generation is a function of education.

To achieve the goals of character education, the role of educators will be the most important. The role of educators in cultivating character is very important, because: 1) they are directly involved in the learning process, so that they will interact a lot with students in the discussion process related to learning materials; 2) as an example for students in behaving and behaving; 3) has a role to be able to encourage students to play an active role in the learning process by using various learning methods that have been adapted to the characteristics of the material and students; 4) must be able to encourage and make changes so that the personality, abilities and desires of educators can create mutually respectful and friendly relationships with their students; 5) must be able to help and develop the emotional and social sensitivity of students to be more cautious, respect God's creation, develop beauty and learn soft skills that are useful for the life of the next student; and 6) must show a sense of love for students so that educators in guiding difficult students do not easily give up (Machin, 2014). 


\section{Quantitative Analysis}

The quantitative analysis was carried out based on the pretest and posttest value data. This analysis was conducted to see the effect of using student worksheets based on a scientific approach on student learning outcomes. The results of the analysis of the pretest and posttest values can be seen in Table 1.

Table 1 Descriptive Data of Pretest and Posttest Values

\begin{tabular}{lllllc}
\hline & $\mathrm{N}$ & Minimum & Maximum & Mean & Std. Deviation \\
\hline PRETEST & 54 & 30.00 & 62.00 & 50.28 & 7.71893 \\
\hline POSTTEST & 54 & 58.00 & 80.00 & 70.17 & 5.55444 \\
\hline Valid N (listwise) & 54 & & & & \\
\hline
\end{tabular}

The pretest was given to students with the aim of knowing their initial conditions. Their mean score at pretest was 50.28, while at the posttest stage it increased to 70.17 (see Table 1). This indicates a significant change in the mean value. This increase in value also occurs in the minimum and maximum scores obtained by students.

To see whether this increase occurred significantly due to the influence of the learning treatment using student worksheets based on a scientific approach, further statistical analysis was carried out. However, before performing statistical tests, the normality of the data is tested first. The results of the normality test can be seen in Table 2 .

Table 2 Results of Data Normality Test of Pretest and Posttest Values

\begin{tabular}{ccccccc}
\hline & \multicolumn{3}{c}{ Kolmogorov-Smirnov $^{\mathrm{a}}$} & \multicolumn{3}{c}{ Shapiro-Wilk } \\
\hline & Statistic & $\mathrm{df}$ & Sig. & Statistic & df & Sig. \\
\hline PRETEST & .139 & 54 & .014 & .923 & 54 & .002 \\
\hline POSTTEST & .135 & 54 & .020 & .957 & 54 & .056 \\
\hline
\end{tabular}

a. Lilliefors Significance Correction

The data in Table 2 shows that the significance value (Sig.) is 0.002 in the pretest data. This value is below the p-value, which is 0.05 , so it can be said that the pretest value is not normally distributed (Muncarno, 2017). It is different with the posttest value data, the significance value (Sig.) Is 0.056 or above the p-value (0.05), so it can be said that the data is normally distributed (Muncarno, 2017). The results of the normality test will determine the test at a later stage. Because one of the data groups is not normally distributed, the statistical test used is nonparametric statistics, namely the Chi Square test.

Table 3 Results of Data Analysis Using Chi Square Test

\begin{tabular}{lccc}
\hline & Value & df & Asymp. Sig. (2-sided) \\
\hline Pearson Chi-Square & $322.251^{\mathrm{a}}$ & 294 & .012 \\
\hline Likelihood Ratio & 158.078 & 294 & 1.000 \\
\hline Linear-by-Linear Association & 26.777 & 1 & .000 \\
\hline N of Valid Cases & 54 & & \\
\hline
\end{tabular}

a. 330 cells (100.0\%) have expected count less than 5. The minimum expected count is .02 .

Chi Square test was conducted to see the effect of treatment (using student worksheets based on a scientific approach) on student learning outcomes. The results of the Chi Square Test can be seen in Table 3. The data in Table 3 shows that the data significance value (Asymp. Sig.) Is 0.012. This value indicates that the use of student worksheets based on a scientific approach affects student learning outcomes. This is because of the Asymp. Sig. is below the p-value (0.05), thus the difference in values that occurs between the two data groups is in a significantly different category (Muncarno, 2017; Siregar and Nara, 2014). 
Statistically, the application of student worksheets based on a scientific approach can affect student learning outcomes. Attitudes are closely related to learning outcomes because students who are active in the learning process will have better learning outcomes than passive ones (Olatunde, 2009; Marsa, Hala, and Taiyeb, 2016; Trumper, 2006). This is because learning media in the form of student worksheets based on a scientific approach are learning media that can be designed and created by teachers to help teachers attract interest and motivate students so that they will be actively involved in the learning process. Student worksheet media can be made according to the characteristics of students, the situation of learning activities at hand, and the conditions of the school environment so that students can express the ideas they get from their observations in the laboratory (Marsa, Hala, and Taiyeb, 2016; Joyce, Weil, and Calhoun, 2009). Thus it will increase the learning activities of students, so it will have implications for the learning outcomes of students.

\section{Conclusion}

Based on the research that has been done, learning by implementing student worksheets based on a scinetific approach can have a positive impact and significant improvement on learning outcomes. In this case, it is devoted to the scientific attitude of students. This shows that the use of student worksheets based on a scientific approach can support the goal of internalizing the attitudes and character of students in learning activities. As is known, the attitudes and character of students are very much needed in producing quality education personnel and of course they act as a balance between the intellectual abilities possessed by each student.

\section{Acknowledgements}

The authors are grateful to Universitas Lampung, who were willing to cooperate in completing this research. The authors also want to thank all those who have helped both material and moral so that this research can be carried out well.

\section{References}

Nirbita, B.N. (2020). Problem Based Learning with ICT for Student's Cognitive. Jurnal Pendidikan dan Pembelajaran Kimia. 9(2): 46-54.

Astalini, Kurniawan, D.A., Perdana, R., dan Pathoni, H. (2019). Identifikasi Sikap Peserta Didik terhadap Mata Pelajaran Fisika di Sekolah Menengah Atas Negeri 5 Kota Jambi. Unnes Physics Education Journal, 8 (1).

Novianto A. dan Mustadi A. (2015). Analisis Buku Teks Muatan Tematik Integratif, Scientific Approach, Dan Authentic Assessment Sekolah Dasar. Jurnal Kependidikan, 45(1), 1-15.

Marini, A., et al. (2019). Model of Student Character Based on Character Building in Teaching Learning Process. Universal Journal of Educational Research, 7(10): 2089-2097.

Wirtha, I.P. dan Rapi, N.K. (2008). Pengaruh Model Pembelajaran dan Penalaran Formal Terhadap Penguasaan Konsep Fisika dan Sikap Ilmiah Siswa SMA Negeri 4 Singaraja. Jurnal Penelitian dan Pengembangan Pendidikan, 1(2): 15-29.

Ribau, I. (2020). Practical Work by Laboratory Stations: An Innovation in Experimental Work. Universal Journal of Educational Research, 8(1): 17-26. 
Afrizon, A. (2012). Peningkatan Perilaku Berkarakter dan Ketrampilan Berpikir Kritis Siswa Kelas IX MTsN Model Padang Pada Mata Pelajaran IPA-Fisika Menggunakan Model Problem Based Instruction. Jurnal Penelitian Pembelajaran Fisika, 2 (1): 1-16.

Albaracin, D., Johnson, B.T., dan Zanna, M.P. (2005). Handbook of Attitude. New Jersey: Lawrence Erlbaum Associates Inc. Publisher.

Machin, A. (2014). Implementasi Pendekatan Saintifik, Penanaman Karakter Dan Konservasi Pada Pembelajaran Materi Pertumbuhan. Jurnal Pendidikan IPA Indonesia. 3 (1): 28-35. http://journal.unnes.ac.id/nju/index.php/jpii

Leksono, S.M. et al. (2013). Kemampuan Profesional Guru Biologi dalam Memahami dan Merancang Model Pembelajaran Konservasi Biodiversitas di SMA.Jurnal Cakrawala Pendidikan,32(3):408-419.

Maretasari, E., Subali, B. dan Hartono (2012). Penerapan Model Pembelajaran Berbasis Laboratorium Untuk Meinniknugikrai Ttekrabnimhbaisnilg Belajar Dan Sikap Ilmiah Siswa. Unnes Physics Education Journal, 1 (2).

Akpinar, E., Yildiz, E., Tatar, N., \& Ergin, Ö. (2009). Students' Attitudes toward Science and Technology: An Investigation of Gender, Grade Level, and Academic Achievement. Procedia Social and Behavioral Sciences, 1(1), 2804-2808.

Kementerian Pendidikan dan Kebudayaan. (2013). Draft Kurikulum 2013. Jakarta: Kemendikbud.

Saefudin, A. dan Saputri, A.E. (2018). Interpreting Scientific Approach in Natural Science Subject for Elementary School: An Integrative Study. Unnes Science Education Journal, 7 (1).

Zimmerman, C. (2007). The development of scientic thinking skills in elementary and middle school. Developmental Review, 27: 172-223.

Nasser, R. (2014). A Methodological and Scientifi c Approach to Developing a Research Agenda in Education. Journal of Applied Sciences, 1-8.

Lederman, N.G., Lederman, J.S., \& Antink, A. (2013). Nature of science and scientific inquiry as contexts for the learning of science and achievement of scientific literacy. International Journal of Education in Mathematics, Science and Technology, 1(3), 138-147.

Setiawan, A., Malik, A., Suhandi, A., and Permanasari, A. (2018). Effect of Higher Order Thinking Laboratory on the Improvement of Critical and Creative Thinking Skills. IOP Conf. Series: Materials Science and Engineering, 306, 012008.

Majid, A. (2012). Perencanaan Pembelajaran. Bandung: PT Remaja Rosdakarya.

Rahmi, Y. L., Novriyanti, E., Ardi, A., \& Rifandi, R. (2018). Developing Guided Inquiry-Based Student Lab Worksheet for Laboratory Knowledge Course. In IOP Conference Series: Materials Science and Engineering, 335(1), 012082.

Permana, D. (2000). Intisari Kimia SMU. Bandung: Pustaka Setia.

Rahmi, L.Y., \& Alberida, H. (2017). Improving Students' Higher Order Thinking Skills through Portfolio Assessment on Biology Curriculum and Textbook Analysis Course. Bioeducation Journal,1(1),22-33.

Departemen Pendidikan Nasional. (2008). Panduan Pengembangan Bahan Ajar. Jakatra: Departemen Pendidikan Nasional Direktorat Jendral Menajemen Pendidikan Dasar dan Menengah.

Marsa, Hala Y., dan Taiyeb A. M. (2016). Pengaruh Penggunaan Lembar Kerja Peserta Didik Berbasis Pendekatan Ilmiah Terhadap Aktivitas dan Hasil Belajar IPA Biologi Kelas VII Peserta Didik SMP Negeri 2 Watampone. Jurnal Sainsmat, 5(1): 42-57. 
Masrizal (2011). Mixed Method Research. Jurnal Kesehatan Masyarakat. 6(1).

Hastjarjo, T.J. (2019). Quasi-Experimental Design. Buletin Psikologi, 27(2): 187 - 203

Sugiyono (2016). Metode Penelitian Pendidikan Pendekatan Kuantitatif, Kualitatif, dan $R \& D$. Bandung: Alfabeta.

Baehaki, F., Nahadi, dan Firman, H. (2016). Pengembangan dan Validasi Tes Pilihan Ganda Berbasis Penalaran Untuk Mengukur Penguasaan Materi Kesetimbangan Kimia. Bandung: Universitas Pendidikan Indonesia.

Yenice, N. And Saydam, G. (2010). $8^{\text {th }}$ Grade Students' science Attitudes and Views About Nature of Scientific Knowledge. Journal of Qafqaz University, 29(1): 89.

Muncarno. (2017). Statistik Pendidikan. Metro-Lampung: Hamim Group.

Olatunde, Y.P. (2009). Students Attitude Towards Mathematics and Academic Achievement in Some Selected Secondary School in Southwestern Nigeria. European Journal of Scientific Research, 36(3): 336-341.

Trumper, Ricardo. 2006. Factors Affecting Junior High School Students' Interest in Physics. Journal of Science Education and Technology, 15(1): 47-58.

Trumper, Ricardo. 2006. Factors Affecting Junior High School Students' Interest in Physics. Journal of Science Education and Technology, 15(1): 47-58.

Siregar, E. and Nara, H. (2014). Teori Belajar dan Pembelajaran. Bogor: Ghalia Indonesia.

Joyce, B., Weil, M., and Calhoun, E. (2009). Models of Teaching. New Jersey: Pearson Education.

\section{Copyrights}

Copyright for this article is retained by the author(s), with first publication rights granted to the journal.

This is an open-access article distributed under the terms and conditions of the Creative Commons Attribution license (http://creativecommons.org/licenses/by/4.0/). 